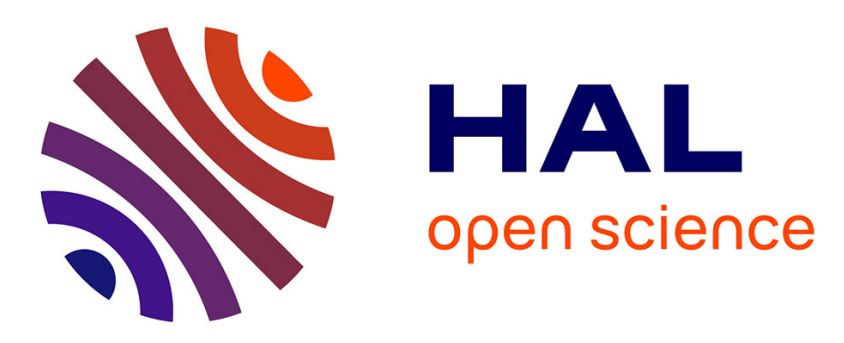

\title{
Effects of atypical antipsychotics on neurocognition in euthymic bipolar patients
}

\author{
Carla Torrent, Anabel Martinez-Arán, Claire Daban, Benedikt Amann, Vicent \\ Balanzá-Martinez, Caterina del Mar Bonnin, Rafael Tabarés-Seisdedos, \\ Eduard Vieta
}

\section{To cite this version:}

Carla Torrent, Anabel Martinez-Arán, Claire Daban, Benedikt Amann, Vicent Balanzá-Martinez, et al.. Effects of atypical antipsychotics on neurocognition in euthymic bipolar patients. 1st International Congress on Neurobiology and Clinical Psychopharmacology and European Psychiatric Association Conference on Treatment Guidance, Nov 2009, Thessaloniki, Greece. pp.S175, 10.1186/1744-859X9-S1-S175 . inserm-00663897

\section{HAL Id: inserm-00663897 https://www.hal.inserm.fr/inserm-00663897}

Submitted on 27 Jan 2012

HAL is a multi-disciplinary open access archive for the deposit and dissemination of scientific research documents, whether they are published or not. The documents may come from teaching and research institutions in France or abroad, or from public or private research centers.
L'archive ouverte pluridisciplinaire HAL, est destinée au dépôt et à la diffusion de documents scientifiques de niveau recherche, publiés ou non, émanant des établissements d'enseignement et de recherche français ou étrangers, des laboratoires publics ou privés. 


\title{
Effects of atypical antipsychotics on neurocognition in euthymic bipolar patients
}

\author{
Carla Torrent ${ }^{*}$, Anabel Martinez-Arán ${ }^{1}$, Claire Daban², Benedikt Amann ${ }^{3}$, Vicent Balanzá-Martinez ${ }^{4}$, \\ Caterina del Mar Bonnin ${ }^{1}$, Rafael Tabarés-Seisdedos ${ }^{4}$, Eduard Vieta ${ }^{1}$ \\ From $1^{\text {st }}$ International Congress on Neurobiology and Clinical Psychopharmacology \\ and European Psychiatric Association Conference on Treatment Guidance \\ Thessaloniki, Greece. 19-22 November 2009
}

\section{Background}

The effect of pharmacological treatment on cognition is still uncertain due to an insufficient number of studies examining this issue.

\section{Materials and methods}

A total of 114 subjects were included in the study. Of 79 DSM-IV euthymic bipolar patients, 63 were treated with one atypical antipsychotic, quetiapine $(\mathrm{n}=12)$, olanzapine $(n=22)$, or risperidone $(n=29)$. Sixteen patients were drug-free. The four groups were compared with a sample of drug-naïve patients and healthy control group $(\mathrm{n}=35)$ on several clinical and neuropsychological variables, especially on the domains of attention, verbal memory and executive functions.

\section{Results}

Bipolar patients taking one of the three antipsychotics presented with dose-independent significant deficits in most cognitive tasks compared to healthy controls. After several head-to-head group comparisons, the patients receiving quetiapine showed a better performance in learning task, short-term memory and recognition task assessed with the California Verbal Learning Test and verbal fluency $(\mathrm{p}<0.05)$.

\section{Conclusions}

Our results confirm previous studies of cognitive deficits in bipolar disorder. Untreated euthymic patients showed better cognitive performance than patients on atypical antipsychotics. Some iatrogenic-pharmacological effect, therefore, can not be excluded but quetiapine seemed to

${ }^{1}$ Bipolar Disorders Program, Clinical Institute of Neuroscience, Hospital Clinic, IDIBAPS, CIBERSAM, University of Barcelona, Barcelona, Spain be less associated with impairment in measures of verbal memory than olanzapine or risperidone. We suggest to use drugs in bipolar disorder with a lower risk of cognitive side-effects. However, randomized controlled trials are urgently needed to give a definite answer to this critical problem.

\section{Acknowledgements}

This study was supported by grants from the Fundacio Marató de TV3 (2510/01), FIS n' PI080180, and the CIBERSAM.

\section{Author details}

'Bipolar Disorders Program, Clinical Institute of Neuroscience, Hospital Clinic, IDIBAPS, CIBERSAM, University of Barcelona, Barcelona, Spain. ${ }^{2}$ INSERM, Pôle de Psychiatrie, Hôpital de Chenevier, Créteil, Paris, France. ${ }^{3}$ Research Unit. CSAM. Psychiatric Hospital Benito Menni, CIBERSAM, St. Boi de Llobregat, Barcelona, Spain. ${ }^{4}$ Department of Medicine, University of Valencia, CIBERSAM, Valencia, Spain.

Published: 22 April 2010

\section{References}

1. Martinez-Aran A, Vieta $E$, Reinares $M$, et al: Cognitive function across manic or hypomanic, depressed, and euthymic states in bipolar disorder. Am J Psychiatry 2004, 161:262-270.

2. Torres IJ, Boudreau VG, Yatham LN: Neuropsychological functioning in euthymic bipolar disorder: a meta-analysis. Acta Psychiatr Scand Suppl 2007, 17-26.

3. Balanza-Martinez V, Rubio C, Selva-Vera G, et al: Neurocognitive endophenotypes (endophenocognitypes) from studies of relatives of bipolar disorder subjects: a systematic review. Neurosci Biobehav Rev 2008, 32:1426-1438.

4. Tabares-Seisdedos R, Balanza-Martinez V, Sanchez-Moreno J, et al: Neurocognitive and clinical predictors of functional outcome in patients with schizophrenia and bipolar I disorder at one-year follow-up. J Affect Disord 2008, 109:286-299.

doi:10.1186/1744-859X-9-S1-S175

Cite this article as: Torrent et al.: Effects of atypical antipsychotics on neurocognition in euthymic bipolar patients. Annals of General Psychiatry 2010 9(Suppl 1):S175. 